\title{
資料
}

医療従事者における保健機能食品の認知の実態

堀西恵理子・根本 蓉子・丸山 智美

(金城学院大学大学院人間生活学研究科)

\section{Recognition of food with health claims by medical staff}

\author{
Eriko Horinishi, Yoko Nemoto and Satomi Maruyama
}

Graduate School of Human Ecology, Kinjo Gakuin University, 2-1723,

Oomori Moriyama-ku, Nagoya-shi, Aichi, 463-8521

干463-8521 愛知県名古屋市守山区大森 2-1723

\begin{abstract}
The use of foods that are labeled with the nutrient function claims has been increasing in Japan. Food with health claims is food having permission from and notification by the national government. It is expected that many questions will emerge about food with health claims directed from patients to the medical staff in a clinical context. However, very little is known regarding the recognition of food with health claims by the medical staff. We studied the existence of food with health claims by requesting 59 medical staff members to fill out a self-entry type questionnaire. Forty-nine staff members $(83.1 \%)$ could recognize the names of foods with health claims that was categorized into two groups; i.e., foods with nutrient function claims and foods for specified health uses. Thirty five staff members (59.3\%) had received such a query from patients, while 39 (66.1\%) lacked information about foods with health claims. Many of the medical staff members wanted to obtain more information through the internet or at a congress. These results suggested that the recognition of and the information about foods with health claims amongst the medical staff members is inadequate.
\end{abstract}

\section{1. 緒言}

機能性食品の世界市場は, アメリカでは105億ドル, ヨーロッパ先進諸国では63億ドルと大きな規模となって いる1）。日本でも家計調查年報の健康保持用摂取品（錠 剂・カプセル等）の支出額 ${ }^{2}$ に世帯数 3$)$ を乗じて算出し た支出額の推計值が，2005年では7447億円で，2001年の 推計值4569億円と比較すると約1.6倍に増加している。 この推計值は, 日本人の栄養補助食品利用額に相当する と考えられ, 機能性食品を含む栄養補助食品の市場拡大 は，我々の食生活に大きな影響を与えていることが予想 される。健康表示のある食品には, 法的根拠を有する食 品と有しない食品とがある。健康増進法の法的根拠があ る食品には, 病者用食品などを含む厚生労働大臣から表 示の許可を必要とする特別用途食品や保健機能食品があ る。「いわゆる健康食品」のうち, 一定の条件を満たし た食品は，栄養改善法と食品衛生法の表示制度を併用し，
特別用途表示制度および栄養表示基準制度により，保健 機能食品と称することができる。保健機能食品は, 国の 許可等の有無や食品の目的, 機能等の違いによって, 特 定保健用食品と栄養機能食品の 2 つのカテゴリーをもつ。 カテゴリーの一つである特定保健用食品は, 個別審査型 （一部企画基準型）の保健機能食品であり, 「特別用途食 品のうち, 食生活において特定の保健の目的が期待でき る旨の表示を厚生労働大臣によって許可されたもの」と 定義されている。平成 17 年 2 月には条件付き特定保健用 食品を創設, 規格基準型の特定保健用食品を創設, 疾病 リスク低減表示を容認することなどの見直しが行われた。 もう一つのカテゴリーである栄養機能食品は栄養素機能 表示むで認める規格基準型の保健機能食品である。法的 根拠を有しない食品には, 健康食品, 栄養補助食品, 機 能性食品など多くの名称がある。健康表示のある食品は 法的基準の有無にかかわらず，現状ではスーパーマーケ ットやコンビニエンスストアや食品を扱うドラッグスト 
アで，だれでも許可なく購入できる。

保健機能食品の役割は病気や生活習慣病などの症状を 直すことではなく不足した栄養素を補い適正な摂取によ って疾病リスクを軽減することであり，治療目的で医療 に使用する医薬品とは異なるとされている。しかし田中 らは地域に㧍ける住民では「病気があるから」「コレス テロールを下げるため」「血圧を下げるため」など疾病 改善のために使用していると回答した者がそれぞれ 5.3 $\% ， 4.7 \% ， 3.6 \%$ 存在したとの報告して抢り，さらに地 域における住民では, 医薬品として栄養を補助する食品 が捉えられている可能性を示唆している ${ }^{4)}$ 。他方, 現在 の日本における臨床現場の医療従事者は, 栄養補助食品 は日常生活に不足している栄養素の補填としての使用だ けでなく, サプリメントについては健診事後指導として 健康支援活動に使用することで予防医学の手段的解決と して大いに期待されている5) ほか，低栄養の改善などに も介入しての使用が試みられている ${ }^{6,7)}$ 。栄養補助食品 利用が増加する社会的背景を受けて, 臨床においては患 者からの質問の増加が推測される。したがって, 医療従 事者が患者に対し正しい治療と情報提供を行うことは, 予防的にも加療的にも専門家としての義務であると考え られる。特に市場に一般食品と同じように流通している 保健機能食品は, 法的根拠がない健康表示のある食品と は区別して，学術的根拠をもって臨床での利用の検討や 患者指導などを行う必要がある。しかし, 医療従事者が 新たに創設された保健機能食品制度を正確に理解してい るか, 患者から保健機能食品の質問をどのような頻度で 受けているか, 職種によって理解度や質問頻度に差はあ るか, などの調査は行われていない。そこで本研究では, 医療従事者の栄養補助食品の情報や知識のあり方を探る ために，特別用途食品に限定することなく，一般食品と 同じ市場に流通している保健機能食品の認知や正しい情 報の入手方法に関する調査を行った。

\section{2. 対象および方法}

平成17年 4 月愛知県で開催された, The $9^{\text {th }}$ Diabetes Educators' Academy（第 9 回 糖尿病教育者アカデ ミー）に参加した医療従事者 147 人を対象に, 調査票を 配布し研究協力を依頼した。参加医療施設は29施設で, 参加医療従事者の職種は表 1 に示したように, 看護師63 人, 薬剤師 23 人, 管理栄養士 22 人, その他の職種（医師, 臨床検査技師, 理学療法土など）39人であった。調査票 の内容は, 保健機能食品の名称と分類, 認識, 患者から の質問経験, 患者への指導 ·提案, 情報入手について,

\section{表 1 参加者の職種}

\begin{tabular}{ccccc}
\hline 看護師 & 薬剤師 & 管理栄養士 & その他 & 計 \\
\hline 63 & 23 & 22 & 39 & 147 \\
\hline
\end{tabular}

表 2 に示した質問票を配布し回答を得た。医療従事者は， 法的根拠の有無について認識していることが必要である ため, 法的根拠に分類されている栄養機能食品と特定保 健用食品を知っているかという認知の有無を尋ねる項目 を設問 1 とした。次にどのような職種が患者からの質問 を受けているかを明らかにするために，患者からの質問 の有無に関する項目およびその内容を設問 2 および 3 と した。食品である保健機能食品をどのような職種が指導 しているかの現状を明らかにするために, 指導提案の有 無を設問 4 とした。他職種が協力のもとチーム医療を推 進し患者教育並びに生活指導を行うためには, 医療従事 者の正確な情報入手は不可欠である。多忙な日常業務の なかで正確に必要量の情報を入手するための効率的な方 法を見出すために, 保健機能食品の情報入手の満足度, 情報入手のための好ましい方法について設問 6 および 7 とした。8 項目のうち, 設問 5 についは, 本研究の目 的である医療従事者の栄養補助食品の情報や知識のあり 方を探る観点から逸脱しているため, 結果および解析対 象からは削除した。

調査票配布時に研究目的, 趣旨の説明を文書で配布し, 本研究は無記名調査であり回答内容は本研究の久に用い られること, The $9^{\text {th }}$ Diabetes Educators' Academy 参加 者の調査結果であることは公表されることがあるが施設 名や個人情報は特定されないこと, 結果の公表に関して は The Diabetes Educators' Academy 幹事会および世話 人会の許可を得て行うものであること, 結果は学会発表 論文などにより広く社会に還元されること, 調査票への 回答は自由意志によるものであることを口頭で説明した。 参加の同意は調査票を提出することで確認するものとし た。調査票は研修会会場で配布し研修会終了時に回収し た。13人は回収時に未提出であったため郵送での回収で あった。回収数は 68 人, 回収率は $46.3 \%$, うち未記入箇 所があった 9 人を除外したため有効回答数 59 人, 有効回 収率 $40.1 \%$ 解析対象とした。解析対象職種は, 表 3 に 示したように, 看護師 26 人, 薬剤師 14 人, 管理栄養士 12 人, その他 7 人 (医師 1 人, 臨床検査技師 5 人, 理学療 法士 1 人) であった。

\section{3. 結 果}

質問票の結果を表 3 に示した。栄養機能食品と特定保 健用食品という名称ならびに厚生労働省による分類があ ることを知っていると答えたものは, 全体では $49 人$ (83.1\%) であった。職業別に見ると, 薬剤師 14 人（100 $\%)$, 管理栄養士は 12 人 $(100 \%)$ 知っており, 看護師で は知っている割合は 26 人中 17 人 $(65.4 \%)$ であった。そ の他の職種は, 7 人中 6 人 $(85.7 \%$ ) (医師 1 人中 0 人, 臨床検査技師 5 人中 5 人, 理学療法士 1 人中 1 人) が知 っていると答えた。患者からの質問経験は, 管理栄養士 10 人 $(83.3 \%)$ が最も高い割合で, ついで薬剤師 14 人 $(71.4 \%)$, 看護師では 12 人 $(46.2 \%)$, その他では 3 人 
保健機能食品についての質問票

「いわゆる健康食品」には多くの種類があります。

厚生労働省が認可したものには, 錠剂やカプセルなどのサプリメントや, 食品の効用や効能を表示した一般の食品 と形態が同じもの（キャンディやビスケット，ジュースなど）があります。

法的に根拠がある食品には, 栄養機能食品と特定保健用食品があり，これらを保健機能食品といいます。

医療現場スタッフは，法的根拠を有する保健機能食品をどのように認識し，指導，利用をしているのかをお伺いし， 今後の栄養教育案の発展に役立てたいと考えております。ご協力を打願いいたします。

回答は，個人ではなく医療スタッフの一員としての立場でお答えください。

あなたの職種 : 医師・看護師・薬剤師・栄養士・その他（）

1. 栄養機能食品と特定保健用食品という名称と分類を知っていましたか？
はい
いいえ

2. 栄養機能食品と特定保健用食品について患者さんから質問を受けたことがありますか？
はい
いいえ

3．2で「はい」と答えた方にお伺いします。質問はどのような内容でしたか？

4. 患者さんに対して，保健機能食品を推奨し，摂取する量や種類などを，指導，提案したことがありますか？
はい
いいえ

5.あなたの職種では，保健機能食品を栄養指導に取り入れたほうが良いと感じますか？
はい
いいえ
ケースバイケースでどちらともいえない

6．あなたの職種では，保健機能食品についての情報は十分に入手できますか？

$$
\text { はい いいえ }
$$

7．6．でいいえと答えた方にお伺いします。

ぞのような情報が不足していると考えますか。具体的にいくつでもご記入ください。

また，どのように情報が入手できると活用できると考えますか。

最も活用したい方法をひとつご記入ください。その理由があれげお書き添えください。 (不足内容 :

$$
\text { 入手方法：理由 }
$$

8. あなたは今までに，保健機能食品を患者さんに勧めたことがありますか？

$$
\text { ある（具体的商品名，栄養素名 ）ない }
$$

調査は以上です。ご協力ありがとうございました。

\begin{tabular}{|c|c|c|c|c|c|c|c|}
\hline 質問項 & & 回答 & $\begin{array}{l}\text { 看護師 } \\
\mathrm{n}=26\end{array}$ & $\begin{array}{c}\text { 薬剤師 } \\
\mathrm{n}=14\end{array}$ & $\begin{array}{c}\text { 管理栄養士 } \\
\mathrm{n}=12\end{array}$ & $\begin{array}{l}\text { その他 } \\
\mathrm{n}=7\end{array}$ & $\begin{array}{c}\text { 人 }(\%) \\
\begin{array}{c}\text { 計 } \\
n\end{array}=59 \\
\end{array}$ \\
\hline 質問 1 & 名称と分類 & $\begin{array}{c}\text { 知っている } \\
\text { 知らない }\end{array}$ & $\begin{array}{r}17(65.4) \\
9(34.6)\end{array}$ & $\begin{array}{c}14(100.0) \\
0(0.0)\end{array}$ & $\begin{array}{c}12(100.0) \\
0(0.0)\end{array}$ & $\begin{array}{l}6(85.7) \\
1(14.3)\end{array}$ & $\begin{array}{l}49(83.1) \\
10(16.9)\end{array}$ \\
\hline 質問 2 & 患者からの質問経験 & $\begin{array}{l}\text { 有 } \\
\text { 無 } \\
\end{array}$ & $\begin{array}{l}12(46.2) \\
14(53.8)\end{array}$ & $\begin{array}{r}10(71.4) \\
4(28.6) \\
\end{array}$ & $\begin{array}{r}10(83.3) \\
2(16.7)\end{array}$ & $\begin{array}{l}3(42.9) \\
4(57.1)\end{array}$ & $\begin{array}{l}35(59.3) \\
24(40.7)\end{array}$ \\
\hline 質問 4 & 指導·提案の経験 & $\begin{array}{l}\text { 有 } \\
\text { 無 } \\
\end{array}$ & $\begin{array}{r}3(11.5) \\
23(88.5) \\
\end{array}$ & $\begin{array}{l}6(42.9) \\
8(57.1) \\
\end{array}$ & $\begin{array}{l}4(33.3) \\
8(66.7) \\
\end{array}$ & $\begin{array}{l}2(28.6) \\
5(71.4)\end{array}$ & $\begin{array}{l}15(25.4) \\
44(74.6)\end{array}$ \\
\hline 質問 5 & 情報入手 & $\begin{array}{l}\text { 十分 } \\
\text { 不十分 }\end{array}$ & $\begin{array}{r}3(11.5) \\
23(88.5)\end{array}$ & $\begin{array}{l}6(42.9) \\
8(57.1)\end{array}$ & $\begin{array}{r}10(83.3) \\
2(16.7)\end{array}$ & $\begin{array}{l}1(14.3) \\
6(85.7)\end{array}$ & $\begin{array}{l}20(33.9) \\
39(66.1)\end{array}$ \\
\hline
\end{tabular}

なお，この調査は研究のためにだけに用いられ，結果は学会および論文などを通じて広く社会に還元いたします。 結果については，分析が終了次第，定例会にて報告いたします。

\section{表 3 保健機能食品についての調査票の結果}


（医師，臨床検査技師，理学療法士各々 1 人) $(42.9 \%)$ が有しており，全体では，35人（59.3\%）であった。患 者からの質問内容は表 4 に示したように，使用許可，量， 効果, 相互作用, 具体的商品についてであった。特に 「治療中でも，保健機能食品を食べて良いか」という使 用許可に関する質問は 12 人が有しており，適量や具体的 な効果, 薬との相互作用よりも高い割合であった。患者 からの質問は，保健機能食品についてではなく栄養補助 食品やいわゆる栄養食品に関する事項も多い，と自由記 述しているものもいた。患者に対して保健機能食品を推 奨したり，摂取する量や種類などを指導提案したことが あるか，という質問に対しては，表 3 に示したように薬 剤師 6 人 $(42.9 \%)$, 管理栄養士 4 人 $(33.3 \%)$, 看護師 3 人 $(11.5 \%)$ があると答えた。保健機能食品は食品で あるが，薬剤師に質問する患者が多い結果であった。具 体的な保健機能食品を患者に勧めたことがあると記述し たものは結果には示さなかったが，管理栄養士 4 人 $(33.3 \%)$, 薬剤師 2 人 $(14.3 \%)$, 看護師 1 人 $(3.8 \%)$ であった。自分の職種では保健機能食品についての情報 は十分に入手できるか，という質問に対しては，看護師 23 人 $(88.5 \%)$, 薬剤師 8 人 $(57.1 \%)$ が不十分と回答 しており，管理栄養士 2 人 $(16.7 \%)$ より高い割合で情 報が不足していると答えた。不足している情報の具体的 な内容について複数回答を得た。表 5 に示したように, 効果の学術的根拠々回答するものが 6 人と最も多く, 次 に効果 5 人，次いで商品形状や競合他社との含有栄養素 比較という種類に関するもの, 副作用, 具体的な商品, 含有栄養素の 4 回答が各々 3 人であった。安全性や相互 作用についての情報が不十分であると回答した者は各々 2 人であった。保健機能食品の情報は，どのように入手 できると活用できると考えるか，という質問を単一回答
で得た。表 6 に示したようにインターネットと回答した ものが 5 人で最も多かった。次いで冊子やパンフレット 4 人, 製造企業の研修会 2 人, 自主的な勉強会などの研 修会 3 人, 学会開催時の商品情報コーナーやランチョン セミナーなどシンポジウムによるもの 2 人であった。イ ンターネットを活用したいと回答したものの理由には, 簡易で迅速であるとの記述があり, 学会を活用したいと 回答したものは，学会に参加している企業であれば信頼 できる，または学会が発信する情報は安心であるとの記 述があった。

\section{4. 考察}

厚生労働省は平成17年「健康食品」の制度の見なおし を行った。これは平成14年に中国製ダイエット食品によ り肝障害から死亡者がでるなど, 社会の中で健康食品に よる健康被害が増加したためである。サプリメントや健 康食品の利用は，高齢者および健康や食生活に対して関 心が高い人たちの利用が高いことが報告されている8)。 高齢社会に向かい，健康への関心が高まっている日本で は健康食品の利用が増加していることが推測される。医 療現場に扔いても, 患者が摂取している割合が増大して いる可能性は高いと考えられる。臨床研究者や実践医療 従事者に拈いても学術集会などで『これからの効果的な 健診事後指導としてのサプリメントの応用』5のような 健康支援活動が提言されるなど，医療従事者による利用 度は高まることが予想される。しかし, 医療現場に打け る栄養補助食品の使用意識や患者からの質問に関しての 調査はほとんどない。健康表示のある栄養を補助する食 品の中には, 販売業者等が独自の判断で販売している 「健康食品」や「いわゆる健康食品」という法律的には 一般食品に属するものも存在する。しかし, 保健機能食

\section{表 4 栄養機能食品と特定保健用食品について患者から受けた質問内容(複数回答)}

\begin{tabular}{llr} 
& & $($ 人) \\
\hline 使用許可 & 治療中でも, 保健機能食品を食べて良いか & 12 \\
量 & 適量はどのくらいなのか & 4 \\
効果 & 具合的な効果を教えて欲しい & 4 \\
相互作用 & 薬との相互作用を教えて欲しい & 3 \\
具体的商品 & 具体的な商品についての質問 $($ 効果·摂取量·根拠) & 3 \\
\hline
\end{tabular}

表 5 不足している情報(複数回答)

\begin{tabular}{lr} 
& (人) \\
\hline 効果の学術的根拠 & 6 \\
効果 & 5 \\
種類 & 3 \\
副作用 & 3 \\
具体的な商品 & 3 \\
含有栄養素 & 3 \\
安全性 & 2 \\
相互作用 & 2 \\
\hline
\end{tabular}

表 6 情報を活用するために活用したい入手方法

\begin{tabular}{lr} 
& $($ 人) \\
\hline インターネット & 5 \\
冊子, パンフレット & 4 \\
製造企業の研修会 & 2 \\
研修会 & 3 \\
学会 & 2 \\
\hline
\end{tabular}


品は薬事法で定められている医薬品と食品衛生法, 食品 安全基本法で規定されている一般食品の中間に位置する 食品である。また，保健機能食品は食品衛生法，食品安 全基本法に加え健康増進法も関与しており，複雑な法規 と多種多様な健康表示のある食品のなかで, 法的に根拠 がある食品としての位置付けをもっている ${ }^{9)}$ 。とこで本 研究では, 厚生労働省による分類が明確である保健機能 食品について, 医療従事者の認識の現状と正確な情報を 入手するための方法を検討するために調査を行った。

保健機能食品を知っているか，という質問に対しては， 薬剤師や管理栄養士では全員が認識していたが，看護師 では $34.6 \%$ が知らないと答えていた。

患者からの質問は，管理栄養士 $83.3 \% ，$ 薬剤師 $71.4 \%$, 看護師 $46.2 \%$ と, 看護師も高い割合で受けていた。

保健機能食品については, 管理栄養士養成校, 薬剂師 養成校では, 食品衛生法や食品安全基本法と薬事法が国 家試験ガイドラインにも明記されており，養成課程カリ キュラムのなかである程度の時間をかけて教育されてい る。医療現場では管理栄養士と薬剤師だけでなく看護師 に対する質問も多いことから, 看護師養成教育のなかで も, 特定保健用食品の知識を薬剂と同様に養成課程もし くは卒後研修などで教育普及することが必要である。患 者からの質問内容には, 摂取の是非を問うものや量, 効 果などが多く, 次いで薬との相互作用であった。保健機 能食品は, 法令上では食品の位置付けであるが, 患者は 一般食品というより薬剤と同様の認識を持っており, 田 中らの地域住民を調査した栄養補助食品の調査報告4)を 追認する結果であった。保健機能食品について医療従事 者として知りたい情報としては，摂取したときの有効性， 有効性の信頼度, 副作用, 安全性への不安などがあげら れていた。医療従事者が必要としている情報は商品その ものや含まれる特定栄養素に関しての科学的根拠である ことが示唆された。保健機能食品は厚生労働省に認可さ れている食品であるので, 効果や安全性には根拠があり, 企業も広報を活発に行っているはずであるが，それらの 情報が医療従事者は十分に入手できていない可能性が確 認された。情報の入手方法では，インターネットを利用 しての企業からの配信, 研修会や学会という回答が得ら れた。インターネットは, 簡易で迅速に入手できるメリ ットがあり, 研修会や学会は信頼度が高いからであると いう回答であった。情報の迅速さと信頼性の両面が患者 に情報提供する立場である医療従事者では必要であるた め, 企業は最新の信頼性を持った情報の提供をすること が必要であることが示唆された。職種別では, 患者から の質問経験が多い薬剤師，管理栄養士のうち，薬剤師は， $57.1 \%$ が情報は不十分であると回答していた。46.2\%が 質問された経験をもつ看護師は $88.5 \%$ が情報は不十分で あると回答していた。薬剤師と看護師に対してさらなる 情報の提供が必要である。管理栄養士は, 情報は比較的 入手しやすいという結果であった。管理栄養士は, 医療
行為のなかで保健点数の加算により栄養指導を行ってい る。栄養と食品の知識を持っていることが責務である職 種であるので, 情報入手が不十分であると回答している ものが $16.7 \%$ というは, 高い割合であるともいえるた め, 管理栄養士に対してもさらなる正しい情報の普及は 必要である。看護師は患者と接する時間が長いため, 会 話の中で保健機能食品の話題に触れる機会が多いと思わ れる。栄養指導を主に担当しない職種であっても, 保健 機能食品の正しい知識や正確な情報を持ち患者との会話 を進めることは医療従事者として必要である。患者に接 する医療従事者が保健機能食品の正しい知識を持たねば ならない一方で, 患者から情報提供や指導を求められた 場合には, 保健機能食品は食品であるので, 一般的な栄 養指導における食品の質問と同様に管理栄養土を通じて 回答するような指導管理体制も必要であることが示唆さ れた。

今後, 保健機能食品はさらに需要が高まり摂取の増加 が予想される。医療現場では, 医療従事者が法的根拠な らびに正しい情報をもっていることが重要である。患者 のおかれた環境やニーズにあわせて保健機能食品の利用 を勧める機会も増加すると思われる。医療従事者は, 患 者が間違った選択をしないように, 根拠のある正確な情 報を提供する義務がある。保健機能食品を製造販売する 企業は医療従事者に対し, 科学的根拠を提供することが 責務である。本調査は糖尿病教育者アカデミーという糖 尿病指導に特化した医療従事者の調査であること, 調査 回答が栄養指導に関与しない多職種も含んでいること, 職種ごとの有効回答数が少ないこと, 施設が愛知県に限 定されていることなど限界がある調査であり, 保健機能 食品の医療現場での使用実態の全てを反映しているわけ ではない。しかし糖尿病という代謝性の疾患の指導を行 う医療従事者においては, 保健機能食品の認識は不十分 であること, 特に情報入手量, 方法ともに不足している ことが示唆され, 医療従事者が抱える保健機能食品への 意識が一部明らかになったと思われる。今後さらに調査 を行ない, 医療現場における保健機能食品の活用の方向 性を探っていく予定である。

\section{5. 要 約}

現在日本では栄養機能が表示されている食品の利用が 増加している。保健機能食品は国の許可を得た食品であ る。臨床現場に颃いても患者から医療従事者に対して保 健機能食品への質問は多いと推測される。しかし, 医療 従事者における保健機能食品の認識の現状については報 告が少ない。そこで本研究は, 法的に根拠がある保健機 能食品について, 医療従事者が持つ認識と情報の入手方 法の現状を明らかにするために, 医療従事者59人を対象 に自記入式調査票を用いて調査を行った。49人 (83.1\%) は栄養機能食品と特定保健用食品という保健機能食品の 名称と厚生労働省による分類を知っていた。25人（59.3 
\%)は患者からの質問経験を有していた。39人（66.1\%） は保健機能食品についての情報は十分に入手できないと 回答した。特定保健用食品や栄養機能食品の情報は，イ ンターネットや学会により入手したいと答えた者が多か った。以上の結果から, 現状では医療従事者は保健機能 食品の知識抢よび認識が不十分であること，情報入手量， 方法ともに不足していることが示唆された。

調査にあたりご協力いただきました名古屋大学医学部 大礒ユタ力教授, 愛知県厚生農業協同組合連合会安城厚 生病院 山本昌弘病院長に感謝申し上げます。本研究結 果公表については，2007年 4 月 23 日開催の The Diabetes Educators' Academy 幹事会および世話人会で許 可を得た。なお, 本研究の一部は, 第29回日本臨床栄養 学会総会（2007年11月，京都）で発表した。

\section{参考文献}

1) Tino Bech-larsen, Joachim Schoederer: Functional foods in Europe:consumer research, market experiences and regulatory aspects. Trends in Food science \& Technology. 18-4, 231-234, 2007

2）家計消費指数結果：平成 14 年基準，総務省統計局, URLhttp://www.stat.go.jp/data/gousei/index02.htm (2007年11月アクセス)

3）平成17年国勢調查報告書 : 世帯の種類別世帯数及び世帯 人員一全国，都道府県（大正 9 年～平成 17 年）

URLhttp://www.stat.go.jp/data/kokusei/2000/kako/setai /index.htm（2007年11月アクセス）
4）第 1 回「健康食品」に係る制度のあり方に関する検討会 （平成15年 4 月 23 日）：健康食品を取り巻く現状, 田中平三： 平成11年度厚生科学研究費「いわゆる栄養補助食品等の流 通実態と食品衛生に関する研究」報告書, 厚生労働省議事 録

URLhttp://www.mhlw.go.jp/shingi/2003/04/s04236b.html（2007年11月アクセス）

5）吉田勝美：これからの効果的な検診事後指導としてのサ プリメントの応用, 第27回日本臨床栄養学総会 - 第 26 回日 本臨床栄養協会総会・第吕回大連合大会プログラム・講演 要旨集, p142, 2005

6）巴美樹, 岩切尚美, 酒井理恵, 瓦林信子, 三瓶彰子, 井 上由紀, 山本茂 : 後期高齢入所者における高齢者用栄養素 補充飲料による栄養状態の改善効果, 栄養学雑誌 : 63:2895, 2005

7）井上啓子, 加藤昌彦 : 在宅要介護高齢者への栄養補助食 品による栄養介入の効果, 日本臨床栄養学会雑誌 : $29: 44-$ 49, 2007

8) J. Satia-Abouta, Kristal A.R., Patternson R.E., Littman A.J., Stratton KL, White E.: Dietary supplement use and medical conditions the vital study. Am. J. Preventive Medicine., $24: 43-51,2003$

9）保健機能食品制度の見直しに伴う特定保健用食品の審査 等取り扱い及び指導要領の改正について（厚生労働省医薬 食品局食品安全部長通知，2005年 2 月 1 日付食安第 0201002 号)

URLhttp://www.nihs.go.jp/hse/food-info/mhlw/news/ 2005/050203/050203-8.pdf（2007年11月アクセス） 